\title{
Quantitative and Qualitative Estimation of Moroccan Trichoderma Isolates Capacity to Solubilize Rock Phosphate
}

\author{
S. KRIBEL, S. QOSTAL, A. OUAZZANI TOUHAMI, K. SELMAOUI, A. MOURIA, \\ R. BENKIRANE, EL. H. ACHBANI and A. DOUIRA* \\ Laboratory of Botany Biotechnology and Plant Protection, Department of Biology, \\ Faculty of Sciences BP. 133, Ibn Tofaill University, Kenitra, Morocco
}

(Received: 10 October 2018; accepted 22 January 2019)

\begin{abstract}
Thirty Trichoderma isolates isolated from compost, various crops and soil with roots of adjacent sites to the phosphate mines of Morocco, were tested in vitro for their potential to solubilize phosphorus from phosphate rock. The qualitative assessment of phosphate solubilization by Trichoderma isolates was performed on Modified Pikovskaya Agar (MPA) solid medium. The visual observation of the 3- and 6-day-old cultures did not show any clear zone around the colony. However, all the isolates were able to grow on the culture medium 3 days after incubation, the maximum recorded diameter was $58.6 \mathrm{~mm}$ for isolate TR-B 98 (3) and the minimum value was $34.8 \mathrm{~mm}$ for isolate TS-EM-98 (2). After 6 days, they showed good radial growth that exceeded 79.8 $\mathrm{mm}$ with variable appearance of the mycelial density such as the isolates TS-B 98, TS-EM-98 (1) and TR-CB 2000 (1) that presented, respectively, high, regular and low mycelial density. Also, the Trichoderma isolates produced variable number of conidia on MPA medium. Quantitative estimation on the Modified Pikovskaya Broth (MPB) liquid medium showed a variable potential of the Trichoderma isolates to solubilize phosphate when the amount of soluble phosphorus remained low in the liquid medium without the fungus $\left(0.26 \mathrm{mgL}^{-1}\right)$. The maximum concentration of soluble phosphorus was $11.92 \mathrm{mgL}^{-1}$ with percentage of soluble phosphorus equal to $95.39 \%$ recorded by the isolate TR-TB 2000 after 9 days of incubation, followed by the isolates TR-B 98 (3), TS-B 98 and TR-EM 2 respectively, 11.20, 10.47 and $9.61 \mathrm{mgL}^{-1}$ and 89.6, 83.76 and $76.38 \%$. In addition, treatments with Trichoderma isolates provided a lower final broth $\mathrm{pH}$ which varied between 6.81 for TOL isolate and 3.40 for TS-B-2000 (2) compared to initial pH (7.2). The isolates that proved potent for phosphate solubilization displayed the highest fresh and dry weights such as TR-TB 2000 (FW=4.11 g and DW $=2.56 \mathrm{~g}$ ), while the lowest fresh and dry weight were noted in the weakest isolates for phosphate solubilization such as $\mathrm{T} 27(\mathrm{FW}=1.025 \mathrm{~g}$ and $\mathrm{DW}=0.58 \mathrm{~g})$.

The high solubilization potential of Trichoderma isolates can be exploited for the solubilization of fixed phosphorus present in the soil, thus improving soil fertility and plant growth.
\end{abstract}

Keywords: Trichoderma isolates, in vitro solubilization, phosphorus, phosphate rock.

Phosphorus (P) is the second most limiting macroelement to plant growth after nitrogen (Wang et al., 2009; Balemi and Negisho, 2012), representing about $0.2 \%$ of the dry matter (Schachtman et al., 1998). It is an essential constituent of phospholipids, adenosine triphosphate (ATP) and nucleic acids (Schachtman et al., 1998), and intervenes in 
various key metabolic processes such as division and cell development, energy transport, transduction, macromolecular biosynthesis, photosynthesis, plant respiration and a large number of signaling processes via protein phosphorylation and dephosphorylation (Shenoy and Kalagudi, 2005; Ahemad et al., 2009; Khan et al., 2009).

Unlike other elements, phosphorus is found only in soil with a soluble P concentration ranging from 0.05 to $10 \mathrm{ppm}$. But most of the phosphorus in the soil is insoluble (Fernández et al., 2007), more than $80 \%$ of the $\mathrm{P}$ becomes unavailable and cannot be absorbed by plants because of its attachment to other elements such as calcium to give $\mathrm{Ca}_{3}\left(\mathrm{PO}_{4}\right)_{2}$ in neutral or alkaline soils, iron and aluminum to give $\mathrm{FePO}_{4}$ and $\mathrm{AlPO}_{4}$ in acidic soils (Altomare et al., 1999) and precipitation or its conversion into organic forms (Holford, 1997).

Solubilization of insoluble phosphorus can be achieved by root phosphatases, but microorganisms also play a significant role, with organic acids or chelates they excrete (Davet, 1996). Many studies have reported that there is a high proportion of phosphate solubilizing microorganisms (PSMs), including bacteria, fungi and Actinomycetes, which live in the plant rhizosphere and play an important role in phosphate solubilization, converting phosphate into soluble compounds for plants (Sujatha et al., 2004; Gravel et al., 2007; Lang et al., 2016).

Fungi of the genus Trichoderma are among the most frequently studied microorganisms as biological control agents and promoters of plant growth (de Terogoff and Ricard, 1976; Kelley, 1976; Gindrat et al., 1977; Davet, 1979; Rishbeth, 1979; Dumitras and Fratilescu-Sesan, 1980; Elad et al., 1981; Yedidia et al., 1999; Harman, 2000; Harman, 2006; Gravel et al., 2007; Vinalea et al., 2008; Achá, 2008; Santos et al., 2010; Oliveira et al., 2012; Kapgate and Rane, 2016). Root colonization by the genus Trichoderma frequently increases root growth, plant development, nutrient uptake, abiotic stress resistance, and consequently productivity (Harman et al., 2004).

Soil microorganisms have been reported to alter soil $\mathrm{pH}$ and the balance of many chemical and biochemical reactions (de Santiago et al., 2013). Fungi, and probably all living organisms, synthesize a number of acidic and alkaline phosphatases in the soil, each of which activates in a distinct $\mathrm{pH}$ range. These are secreted in response to the signals of the absence of P (Peleg et al., 1996).

Studies have demonstrated the ability of Trichoderma species to promote the growth of several types of plants and protect them against plant pathogens (Kapri and Tewari, 2010; Santos et al., 2010; Machado et al., 2011; Hannan et al., 2013) and to improve the bioavailability of phosphorus by reducing the need for inorganic phosphates. This capacity is favored by the production of phytases and certain organic acids such as citric acid, lactic acid, and succinic acid by different strains of Trichoderma spp. (Promwee et al., 2014).

The present study was undertaken to estimate in vitro the capacity of 30 Trichoderma isolates to solubilize the crude phosphate rock originating from the phosphate mines of Khouribga (Morocco). 


\section{Materials and Methods}

\section{Fungal material}

Seven Trichoderma isolates belonging to the Botanical Laboratory, Biotechnology and Plant Protection Laboratory (LBBPP) (originating from compost and different crops, two isolates of Trichoderma asperellum were registered in NCBI database) and twentythree isolates newly isolated from sites adjacent to the phosphate mines of Morocco (Table 1) were grown on PSA (Potato sucrose Agar) medium (potato $200 \mathrm{~g}$, sucrose $20 \mathrm{~g}$, Agar-agar: $15 \mathrm{~g}$, distilled water $1000 \mathrm{ml}$ ) and incubated at $28 \pm 1{ }^{\circ} \mathrm{C}$ in the dark.

\section{Inorganic phosphate}

Crude phosphate rock $\left(\mathrm{BPL}^{*}=68\right.$ (*bone phosphate of lime with $31.12 \% \mathrm{P}_{2} \mathrm{O}_{5}$ content)) from the phosphate mines of Khouribga (Morocco) was ground in a porcelain mortar and washed 3 times with tap water to remove soluble phosphorus.

Study of the capacity of Trichoderma isolates to solubilize phosphate

\section{Qualitative estimation}

The ability of Trichoderma isolates to solubilize inorganic phosphate was tested on the MPA medium (Modified Pikovskaya Agar): Phosphate rock powder: $2.5 \mathrm{~g}$; Glucose: $13 \mathrm{~g} ;\left(\mathrm{NH}_{4}\right) \mathrm{SO}_{4}: 0.5 \mathrm{~g}$; NaCl: $0.2 \mathrm{~g} ; \mathrm{MgSO}_{4}, 7 \mathrm{H}_{2} \mathrm{O}: 0.1 \mathrm{~g} ; \mathrm{KCl}: 0.2 \mathrm{~g}$; Yeast extract: $0.5 \mathrm{~g} ; \mathrm{MnSO}_{4}: 0.0002 \mathrm{~g} ; \mathrm{FeSO}_{4}, 7 \mathrm{H}_{2} \mathrm{O} ; 0.0002 \mathrm{~g}$; Agar-agar: $15 \mathrm{~g}$; the $\mathrm{pH}$ was adjusted to 7.2 using a pH meter and the components were dissolved in $1000 \mathrm{ml}$ of distilled water (Pikovskaya, 1948).

A 5-mm mycelial disk from the 7-day-old culture of each Trichoderma isolate was placed in the center of the agar plate and incubated at $28{ }^{\circ} \mathrm{C}$. After 3 and 6 days of incubation, the colony and the halo-zone diameters were measured by a double decimeter. The phosphate solubilization index (PSI) was calculated according to the following formula (Alam et al., 2002; Afzal and Asghari, 2008):

$$
\text { PSI }=\frac{\text { The colony diameter }+ \text { The halo-zone diameter }}{\text { The colony diameter }}
$$

To determine the number of the conidia produced, three 5-mm discs were taken from the 7-day-old cultures on MPA for each Trichoderma isolates, put in a test tube containing $1 \mathrm{ml}$ of sterile distilled water and shaken for 5 min using an orbital shaker at $30 \mathrm{rpm}$. The conidia concentration was measured using a Malassez slide.

The density of mycelia was identified by visual observation after 7 days when Trichoderma isolates complete colonization of the Petri dishes of MPA using a scale of Sobal et al. (2007): (High density: +++ ; Regular density: ++ ; Low density: + ). 


\section{Quantitative estimation}

Trichoderma isolates were tested for their ability to solubilize inorganic phosphate in Modified Pikovskaya Broth (MPB): Phosphate rock powder: $2.5 \mathrm{~g}$; Glucose: $13 \mathrm{~g}$; $\left(\mathrm{NH}_{4}\right) 2 \mathrm{SO}_{4}: 0.5 \mathrm{~g} ; \mathrm{NaCl}: 0.2 \mathrm{~g} ; \mathrm{MgSO}_{4}, 7 \mathrm{H}_{2} \mathrm{O}: 0.1 \mathrm{~g} ; \mathrm{KCl}: 0.2 \mathrm{~g}$; Yeast extract: $0.5 \mathrm{~g}$; $\mathrm{MnSO}_{4}: 0.0002 \mathrm{~g} ; \mathrm{FeSO}_{4}, 7 \mathrm{H}_{2} \mathrm{O}: 0.0002 \mathrm{~g}$; the $\mathrm{pH}$ was adjusted to 7.2 and the components were dissolved in $1000 \mathrm{~mL}$ of distilled water (Pikovskaya, 1948).

Five 5-mm mycelial disks from each Trichoderma isolate were inoculated into a $250 \mathrm{~mL}$ Erlenmeyer flask containing $100 \mathrm{~mL}$ broth and incubated at $28{ }^{\circ} \mathrm{C}$ in a shaker

\section{Table 1}

Origin and sources of isolation of Trichoderma isolates tested

\begin{tabular}{|c|c|c|}
\hline Trichoderma isolates & Sources of isolation & Locality (country) \\
\hline $\begin{array}{l}\text { T1 (BankIt1902509 SMis1 } \\
\text { KU987252) } \\
\text { Trichoderma asperellum }\end{array}$ & TTC Compost & Missour/Morocco \\
\hline 1TH & Bananas agriculture/Mnasra & Kenitra region/Morocco \\
\hline TH2 & Bananas agriculture/Mnasra & Kenitra region/Morocco \\
\hline $\begin{array}{l}\text { T27 (BankIt1902509 } \\
\text { SDLA27 KU987250) } \\
\text { Trichoderma asperellum }\end{array}$ & Strawberry agriculture, Festival variety & Dlalha/My Bouselham/Morrocco \\
\hline T 30 & Strawberry agriculture, Sabrina variety & Gnafda/My Bouselham/Morocco \\
\hline TOL & Roots of an olive tree & Sidi Kacem/Morocco \\
\hline TY & Rhizosphere of the roots of an olive tree & Sidi Kacem/Morocco \\
\hline TS-BG & Soil of Bengurir region & Bengurir region/Morocco \\
\hline TS-ML & Soil of Mrah Lahrech site & \\
\hline TS-H & Hattan site soil & \\
\hline TS-RP & Pure phosphate rock & \\
\hline TR-OL 1 & Rhizosphere of the roots of an olive tree & \\
\hline TR-OL 2 & Rhizosphere of the roots of an olive tree & \\
\hline TR-CB 2000 (2) & $\begin{array}{l}\text { Root rhizosphere of a Crucifera } \\
\text { Agriculture, sludge } 2000\end{array}$ & \\
\hline TR-TB 2000 & Roots of Tamarix, sludge 2000 & \\
\hline TS-B 98 & Sludge soil 1998 & \\
\hline TS-EM 98 (1) & Sludge soil 1998 & \\
\hline TS-EM 98 (2) & Sludge soil 1998 & \\
\hline TR-EM 1 & Roots of mixed plant samples & Khouribga region/Morocco \\
\hline TR-EM 2 & Roots of mixed plant samples & \\
\hline TR-B 98 (1) & Sludge roots 1998 & \\
\hline TR-B 98 (2) & Sludge roots 1998 & \\
\hline TR-B 98 (3) & Sludge roots 1998 & \\
\hline TS-B 98/2002 (1) & Sludge roots $1998 / 2002$ & \\
\hline TS-B 98/2002 (2) & Sludge roots $1998 / 2002$ & \\
\hline TR-B 98/2002 (1) & Sludge roots $1998 / 2002$ & \\
\hline TR-B 98/2002 (2) & Sludge roots $1998 / 2002$ & \\
\hline TS-B 2000 (1) & Sludge soil 2000 & \\
\hline TS-B 2000 (2) & Sludge soil 2000 & \\
\hline TR-C B 2000 (1) & Sludge cruciferous roots 2000 & \\
\hline
\end{tabular}


(GFL 3020) at $120 \mathrm{rpm}$ for 7 days. The broths were filtered through Whatman $\mathrm{N}^{\circ} 1$ paper $(0.45 \mu \mathrm{m})$ and centrifuged at 5,000 rpm for $10 \mathrm{~min}$ to remove spores and mycelium of Trichoderma isolates.

The $\mathrm{pH}$ of each culture was measured using a $\mathrm{pH}$ meter. The phosphorus concentration in the supernatant was estimated spectrophotometrically (Fiske and Subbarow, 1925; Saravanakumar et al., 2013). An aliquot of $750 \mu \mathrm{l}$ of culture supernatant was mixed with $750 \mu \mathrm{l}$ of the colored reagent containing ammonium molybdate $\left(\left(\mathrm{NH}_{4}\right) 6 \mathrm{Mo}_{7} \mathrm{O}_{24}, 4 \mathrm{H}_{2} \mathrm{O}\right)$ $1.5 \%(\mathrm{w} / \mathrm{v})$, sulfuric acid solution $\left(\mathrm{H}_{2} \mathrm{SO}_{4}\right) 5.5 \%(\mathrm{v} / \mathrm{v})$ and $2.7 \%(\mathrm{w} / \mathrm{v})$ ferrous sulphate solution $\left(\mathrm{FeSO}_{4}\right)$ and then measured by a UV-visible spectrophotometer at $600 \mathrm{~nm}$. The level of phosphorus concentration was determined using the standard potassium dihydrogen phosphate curve $\left(\mathrm{KH}_{2} \mathrm{PO}_{4}\right)$ and expressed as equivalent phosphorus in mg-P.L ${ }^{-1}$.

The percentage of soluble phosphorus in the culture filtrates was estimated at the 9th day of incubation, where the soluble phosphorus concentration reached the maximum for all isolates, using the formula:

$$
\% \text { of soluble } \mathrm{P}=\frac{\text { Soluble phosphorus concentration in filtrate } \times 100}{\text { Initial phosphate concentration }}
$$

\section{Measurement of mycelial biomass of different Trichoderma isolates in broth cultures}

The fungal mycelium was harvested after 12 days of incubation and separated from the culture liquid by filtration through Whatman No. 1 filter paper. The fresh weight of the mycelium was measured using a weighting scale. Then the mycelial pellet was dried at $70{ }^{\circ} \mathrm{C}$ for $24 \mathrm{~h}$ and the dry weight of the fungus was calculated using a precision weighting scale using the following formula:

Dry weight $=($ weight of filter paper + mycelium $)-($ weight of filter paper $)$

\section{Statistical analysis}

All the experiments were performed in triplicate for each isolate and the Blanc. Statistical data processing included analysis of variance using ANOVA I and LSD test at $5 \%$ level.

\section{Results}

Study of the capacity of Trichoderma isolates to solubilize phosphate

\section{Qualitative estimation}

After 3 days of incubation at $28^{\circ} \mathrm{C}$, all the Trichoderma isolates were able to grow on MPA solid medium but no clear zone around the mycelial colony was observed to estimate phosphate solubilization (Fig. 1). The cultures were also monitored after 6 days 

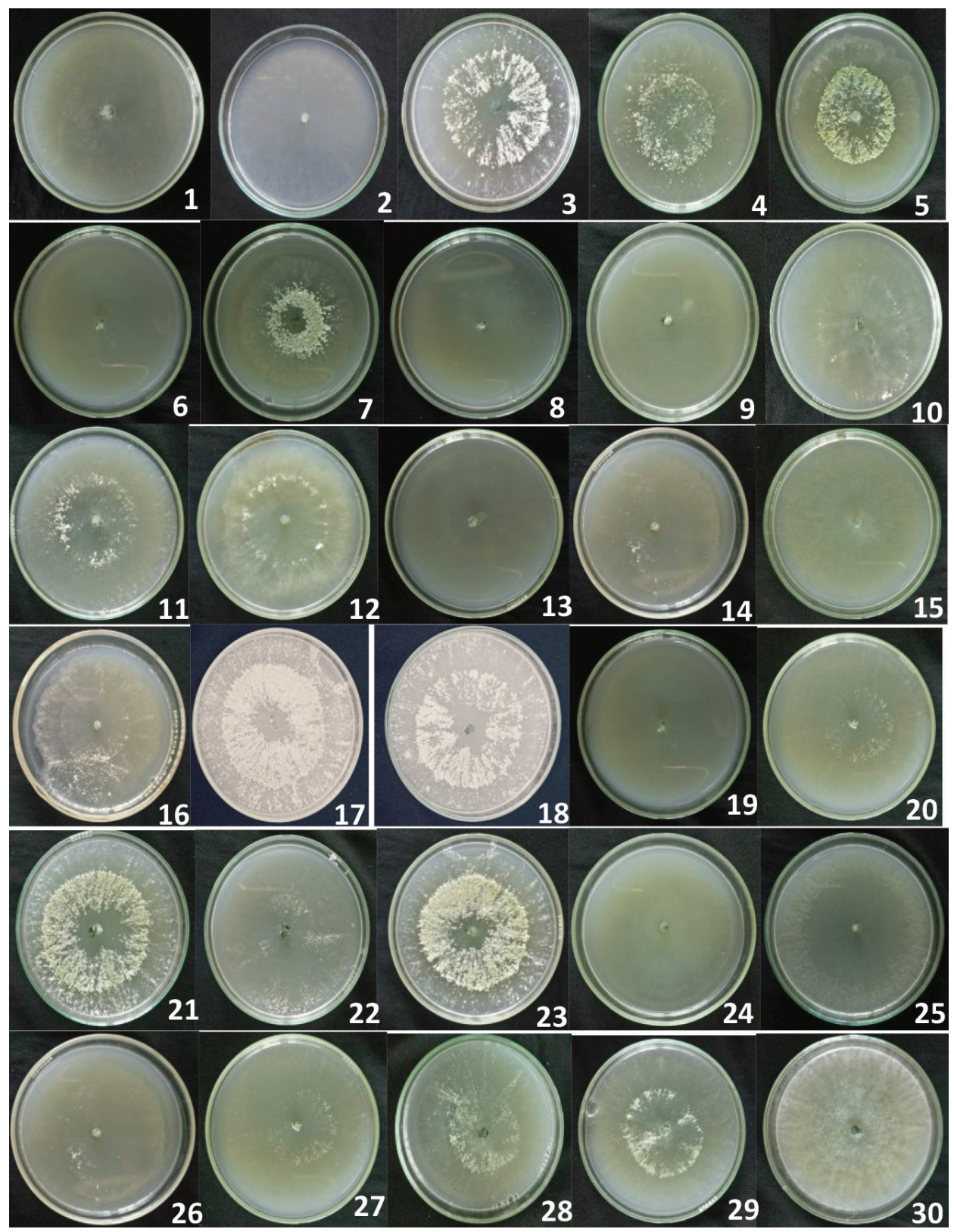

Fig 1. Absence of the halo-zone around the culture

of Trichoderma isolates on modified Pikovskaya agar medium (MPA)

$\mathbf{1}$ : TR-EM $2 ; \mathbf{2}$ : TR-CB 2000 (1) ; 3 : T27 ; 4 : TR-B-98 (2); 5 : TH$_{2} ; \mathbf{6}$ : TS-B 98/2002 (1); 7 : TR-OL (1) $; \mathbf{8}:$ TY ; 9 : TOL ; $\mathbf{1 0}:$ TR-TB $2000 ; \mathbf{1 1}:$ TS-H ; 12 : TS-BG ; $\mathbf{1 3}:$ T30 ; 14 : TR-EM $1 ; \mathbf{1 5}$ : TR-B 98 (1); $\mathbf{1 6}$ : T1 ; 17 : TR-B 98/2002 (2) ; 18 : TR0L $2 ; \mathbf{1 9}$ : TR-CB 2000 (2) ; 20 : TS-B 2000 (2) ; 21 : TR-B 98 (3); 22 : TS-EM 98 (1) ; 23 : TS-B 98 ; 24 : TS-B 2000 (1) ; 25 : 1TH ; 26 : TS-RP ; 27 : TS-B 98/2002 (2) ; 28 : TS-ML ; 29 : TS-EM 98 (2) ; 30 : TR-B 98/2002 (1). 
without the observation of any halo - zone, so the phosphate solubilization index was not calculated.

The isolates TR-B 98 (3); TS-B-2000 (2); T30; TR-B 98/2002 (1); 1TH; TR-B 98/2002 (2); TR-OL 2; TR-EM 1; TR-TB 2000; TS-BG; TR-EM 2; TS-B 2000 (1) showed a radial colonies that diameters varied between 51.0 and $58.6 \mathrm{~mm}$ on 3 -days old cultures, followed by T1; $\mathrm{TH}_{2}$; TOL; TY; TS-ML; TS-H; TS-B 98/2002 (2); TR-CB 2000 (2); TR-CB 2000 (1) ; TS-RP ; TR-B 98 (1); TR-B 98 (2) with colony diameters

Table 2

Growth and conidia production of Trichoderma isolates in the modified Pikovskaya agar (MPA) supplemented with rock phosphate (RP)

\begin{tabular}{|c|c|c|c|c|}
\hline \multirow[t]{2}{*}{ Isolates } & \multicolumn{2}{|c|}{ Colony diameter $(\mathrm{mm})$} & \multirow[t]{2}{*}{ Mycelium Density } & \multirow{2}{*}{$\begin{array}{l}\text { Conidia production } \\
\left(\text { Conidia } / \mathrm{mm}^{2}\right)\end{array}$} \\
\hline & After 3 days & After 6 days & & \\
\hline T1 & $43.3^{\mathrm{d}}$ & $85^{\mathrm{b}}$ & ++ & $8492.55^{\mathrm{e}}$ \\
\hline 1TH & $54.1^{\mathrm{b}}$ & $90^{\mathrm{a}}$ & + & $0^{\mathrm{i}}$ \\
\hline $\mathbf{T H}_{2}$ & $47.5^{\mathrm{d}}$ & $90^{\mathrm{a}}$ & +++ & $8492.55^{\mathrm{e}}$ \\
\hline TOL & $42.5^{\mathrm{de}}$ & $80^{\mathrm{bc}}$ & + & $0^{\mathrm{i}}$ \\
\hline $\mathbf{T} 27$ & $50.5^{\mathrm{c}}$ & $90^{\mathrm{a}}$ & +++ & $10191.06^{\mathrm{d}}$ \\
\hline T30 & $57.8^{\mathrm{a}}$ & $90^{\mathrm{a}}$ & + & $0^{\mathrm{i}}$ \\
\hline TY & $46^{d}$ & $90^{\mathrm{a}}$ & + & $0^{\mathrm{i}}$ \\
\hline TS-ML & $43.3^{\mathrm{d}}$ & $90^{\mathrm{a}}$ & ++ & $8492.55^{\mathrm{e}}$ \\
\hline TS-H & $45.3^{d}$ & $90^{\mathrm{a}}$ & +++ & $8492.55^{\mathrm{e}}$ \\
\hline TS-B 2000 (1) & $51.0^{\mathrm{c}}$ & $90^{\mathrm{a}}$ & + & $0^{\mathrm{i}}$ \\
\hline TS-B 98/2002 (1) & $54^{\mathrm{b}}$ & $90^{\mathrm{a}}$ & + & $0^{\mathrm{i}}$ \\
\hline TS-B 98/2002 (2) & $45.6^{\mathrm{b}}$ & $90^{\mathrm{a}}$ & + & $0^{\mathrm{i}}$ \\
\hline TR-B 98/2002 (1) & $55.1^{\mathrm{b}}$ & $90^{\mathrm{a}}$ & + & $0^{\mathrm{i}}$ \\
\hline TR-B 98/2002 (2) & $54.1^{\mathrm{b}}$ & $90^{\mathrm{a}}$ & +++ & $44161.26^{\mathrm{b}}$ \\
\hline TR-OL 2 & $54.0^{\mathrm{b}}$ & $90^{\mathrm{a}}$ & +++ & $33970.2^{c}$ \\
\hline TS-EM-98 (1) & $39.8^{\mathrm{e}}$ & $90^{\mathrm{a}}$ & ++ & $8492.55^{\mathrm{e}}$ \\
\hline TR-CB 2000 (2) & $46.6^{d}$ & $90^{\mathrm{a}}$ & + & $0^{\mathrm{i}}$ \\
\hline TS-B-2000 (2) & $58.5^{\mathrm{a}}$ & $90^{\mathrm{a}}$ & ++ & $10191.06^{\mathrm{d}}$ \\
\hline TR-CB 2000 (1) & $41.1^{\mathrm{e}}$ & $83.3^{\mathrm{b}}$ & + & $8492.55^{\mathrm{e}}$ \\
\hline TS-EM-98 (2) & $34.8^{\mathrm{e}}$ & $90^{\mathrm{a}}$ & ++ & $3397.02^{g}$ \\
\hline TR-TB 2000 & $51.8^{\mathrm{c}}$ & $90^{\mathrm{a}}$ & ++ & $3397.02^{\mathrm{g}}$ \\
\hline TS-BG & $51.6^{\mathrm{c}}$ & $90^{\mathrm{a}}$ & +++ & $5095.35^{\mathrm{f}}$ \\
\hline TR-OL 1 & $39.5^{\mathrm{e}}$ & $85^{\mathrm{b}}$ & +++ & $8492.55^{\mathrm{e}}$ \\
\hline TS-RP & $40.6^{\mathrm{e}}$ & $79.8^{\mathrm{c}}$ & + & $1698.51^{\mathrm{h}}$ \\
\hline TR-EM 1 & $53.3^{c}$ & $90^{\mathrm{a}}$ & ++ & $3397.02^{\mathrm{g}}$ \\
\hline TS-B 98 & $57.3^{\mathrm{a}}$ & $90^{\mathrm{a}}$ & +++ & $59447.85^{\mathrm{a}}$ \\
\hline TR-EM 2 & $51.3^{\mathrm{c}}$ & $90^{\mathrm{a}}$ & + & $0^{\mathrm{i}}$ \\
\hline TR-B 98 (1) & $45.0^{\mathrm{d}}$ & $90^{\mathrm{a}}$ & ++ & $0^{\mathrm{i}}$ \\
\hline TR-B 98 (2) & $46.3^{d}$ & $90^{\mathrm{a}}$ & +++ & $13588.08^{\mathrm{c}}$ \\
\hline TR-B 98 (3) & $58.6^{\mathrm{a}}$ & $86.6^{\mathrm{b}}$ & +++ & $59447.85^{\mathrm{a}}$ \\
\hline
\end{tabular}

Two values in the same column show no significant difference at the $5 \%$ level if they are affected by the same letter. 


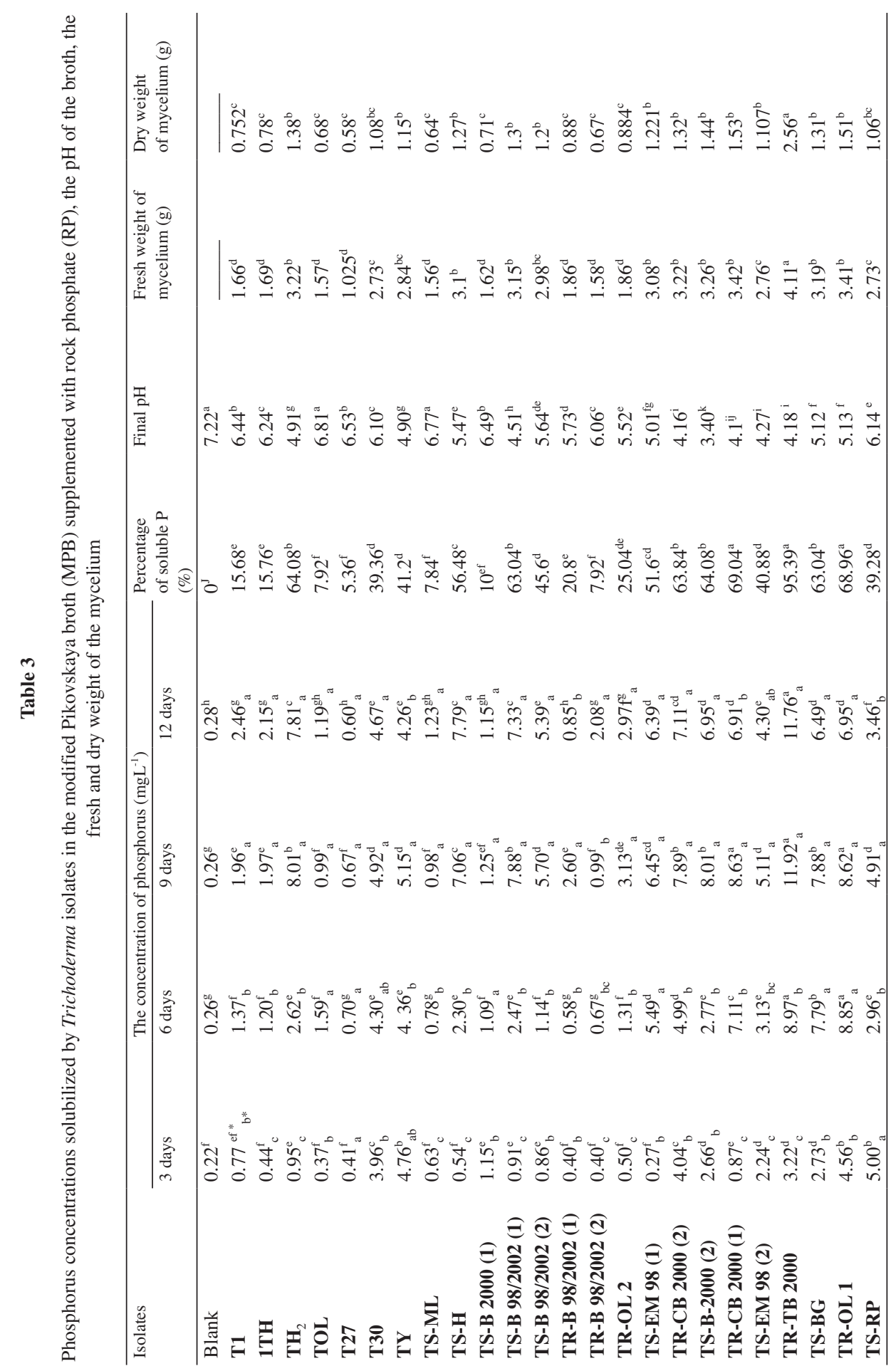




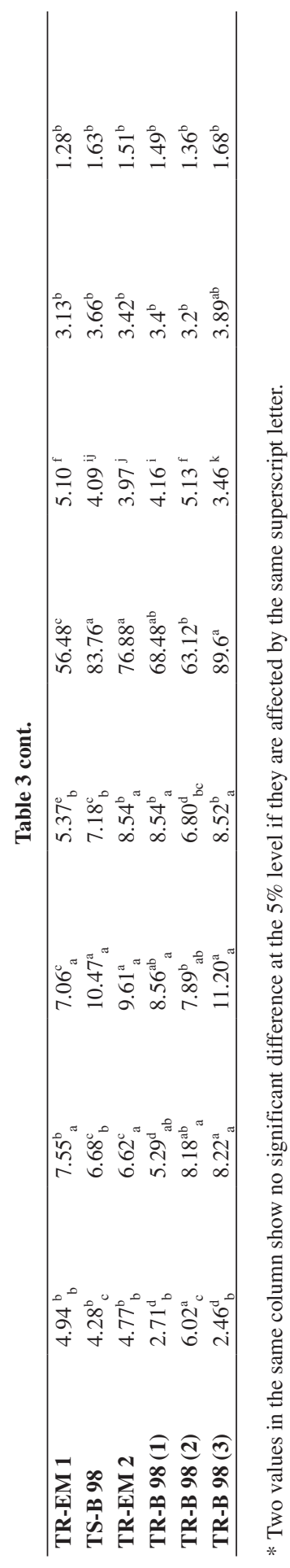


ranging from 46.3 to $43.3 \mathrm{~mm}$ and the isolates TS-EM 98 (1); TS-EM 98 (2); TR-OL 1 with radial growth ranging from 34.8 to $39.5 \mathrm{~mm}$. After 6 days, the Trichoderma isolates continued to grow on MPA medium reaching $90 \mathrm{~mm}$ except isolates T1; TR-CB 2000 (1); TR-OL 1; TS-RP; TR-B 98 (3) that colony diameters varied between $79.8 \mathrm{~mm}$ and $86.6 \mathrm{~mm}$ (Table 2).

The mycelial density of Trichoderma isolates was variable on the MPA solid medium after 7 days of incubation. The isolates $\mathrm{TH}_{2}$; T27; TS-H; TR-B 98/2002 (2); TR-OL 2; TS-BG; TR-OL 1; TS-B 98; TR-B 98 (3); TR-B 98 (2) displayed high mycelial density, followed by T1; TS-ML; TS-EM-98 (1); TS-B-2000 (2); TS-EM-98 (2); TR-TB 2000; TR-EM 1; TR-B 98 (1), showing a regular mycelial density. However, the isolates 1TH; TOL; T30; TY; TS-B 2000 (1); TS-B 98/2002 (1); TS-B 98/2002 (2); TR-B 98/2002 (1); TR-CB 2000 (2); TR-CB 2000 (1); TS-RP; TR-EM 2 exhibited low mycelial density (Table 2).

The conidia production by the Trichoderma isolates was estimated on the 7-day-old cultures. The isolates TR-B 98 (2), TR-OL 2, TR-B 98/2002 (2), TS-B 98, TR-B 98 (3) produced an important number of conidia with values ranging from 13588.08 to 59447.85 conidia. $\mathrm{mm}^{-2}$, succeeded by the isolates T1, TH 2 , T2, TS-ML, TS-H, TS-EM-98 (1), TS-B-2000 (2), TR-CB 2000 (1), TS-EM-98 (2), TR-TB 2000, TS-BG, TR-OL 1, TS-RP, TR-EM 1, with a conidia number varying between 3397.02 and 10191.06 conidia. $\mathrm{mm}^{-2}$. Finally, the other isolates were unable to produce conidia (Table 2).

\section{Quantitative estimation}

A gradual increase with time of the soluble phosphorus concentrations was observed in culture filtrates of the 30 Trichoderma isolates tested after 3, 6 and 9 days of incubation but decreased slightly the $12^{\text {th }}$ day when the amount of soluble phosphorus remained low in the liquid medium without the fungus (Table 3).

Three days after inoculation, the Trichoderma isolates TR-B98 (2) and TS-RP gave a best soluble phosphate concentrations, respectively, 6.02 and $5 \mathrm{mgL}^{-1}$ compared to the blank $\left(0,22 \mathrm{mgL}^{-1}\right)$, followed by TR-EM (1), TR-EM 2, TY, TR-OL 1, TS-B 98 and TR-CB 2000 (2), with phosphorus concentrations ranging from 4.04 to $4.94 \mathrm{mg} \mathrm{L}^{-1}$. T30 (3.96 $\left.\mathrm{mgL}^{-1}\right)$ and TR-TB $2000\left(3.22 \mathrm{mgL}^{-1}\right)$. The isolates TS-BG, TR-B 98 (1), TS-B 2000 (2), TR-B 98 (3) and TS-EM 98 (2) showed moderate phosphorus concentrations ranging from 2.24 to $2.73 \mathrm{mg} \mathrm{L}^{-1}$ when the other isolates not exceeding $1.15 \mathrm{mgL}^{-1}$.

After the $6^{\text {th }}$ day of incubation, the isolates TR-TB 2000; TR-OL (1); TR-B 98 (3); TR-B 98 (2); TR-CB 2000 (1); TR-EM (1); TS-BG revealed a very good ability to solubilize rock phosphate by increasing soluble phosphorus concentrations in culture filtrates varying from 7.11 to $8.97 \mathrm{mgL}^{-1}$. The blank's concentration remained low, equal to $0.26 \mathrm{mgL}^{-1}$.

All Trichoderma isolates continued to solubilize rock phosphate even after 9 days of incubation. The isolates that performed best were $\mathrm{TH}_{2}$; TS-H; TS-B 98/2002 (1); TR-CB 2000 (2); TS-B 2000 (2); TR-CB 2000 (1); TR-TB 2000; TS-BG; TR-OL 1; TR-EM (1), TS-B 98; TR-EM 2; TR-B 98 (1); TR-B 98 (2); TR-B 98 (3), with concentrations exceeding $7 \mathrm{mgL}^{-1}$. But an insignificant decrease in phosphorus concentrations was noted after 12 days of incubation.

The concentrations of soluble phosphorus in the liquid medium without Trichoderma isolates remained low after 9 and 12 days incubation not exceeding $0.28 \mathrm{mgL}^{-1}$. 
The Trichoderma isolates exhibited also variable soluble phosphorus percentages in 9 days culture filtrates. The isolates TR-TB 2000, TR-B 98 (3), TS-B 98 and TR-EM 2 isolates showed high soluble phosphorus percentages equal to $95.39,89.6,83.76$ and $76.88 \%$, followed by $\mathrm{TH}_{2}$, TS-H, TS-B 98/2002 (1), TS-EM 98 (1), TR-CB 2000 (2), TSB-2000 (2), TR-CB 2000 (1), TS-BG, TR-OL 1, TR-EM 1, TR-B 98 (1), TR-B 98 (2) with soluble phosphorus percentages ranging from 51.6 to $69.04 \%$. Then the T30, TY, TS-B 98/2002 (2), TR-B 98/2002 (1), TR-OL 2, TS-EM 98 (2), TS-RP isolates showed varying percentages between 20.8 and $45.6 \%$. Finally the $1 \mathrm{TH}, \mathrm{TH}_{2}, \mathrm{TOL}, \mathrm{T} 27, \mathrm{TS}-\mathrm{ML}, \mathrm{TS}-\mathrm{B}$ 2000 (1), TR-B 98/2002 (2) isolates proved to be very weak for the solubilization of rock phosphate with percentages less than $15.76 \%$.

Treatments with Trichoderma isolates provided a lower final $\mathrm{pH}$ compared to the initial $\mathrm{pH}$ of the broths (7.2). The culture filtrates of the Trichoderma isolates TS-B 2000 (2), TR-EM (2) and TR-B98 (3) displayed a lower final pH less than 4, followed by $\mathrm{TH}_{2}$, TS-B 98/2002 (1), TY, TR-CB 2000 (2), TR-CB 2000 (1), TR-TB 2000, TS-B 98, the pH was under 5. The other isolates gave a final $\mathrm{pH}$ of 5.01 and 6.81 (Table 3).

The fresh and dry weights of the mycelium were estimated after the 12th day of incubation. The highest fresh and dry weights were noted in TR-TB 2000 isolate (FW=4.11 g and $\mathrm{DW}=2.56 \mathrm{~g}$ ) followed by the isolates $\mathrm{TH}_{2}$; TS-H; TS-B 98/2002 (1); TS-EM 98 (1); TR-CB 2000 (2); TS-B-2000 (2); TR-CB 2000 (1); TS-BG; TR-OL 1; TR-EM 1; TS-B 98; TR-EM 2 having fresh weights ranging from 3.89 to $3.08 \mathrm{~g}$ and dry weights ranging from 1.68 to $1.221 \mathrm{~g}$. While other isolates have fresh weights ranging from 1.025 to 2.98 $\mathrm{g}$ and dry weights ranging from 0.58 to $1.2 \mathrm{~g}$ (Table 3 ).

\section{Discussion}

The Trichoderma isolates isolated from compost, various crops and soil with roots of adjacent sites to the phosphate mines of Morocco, were tested in vitro for their potential to solubilize phosphorus from phosphate rock in liquid and solid Pikovskaya medium. Thus, the qualitative estimate of the ability to solubilize phosphate by Trichoderma isolates revealed that all isolates did not show any clear zone around colonies on the agar plate but gave good mycelial growth with variable mycelial density and conidia production. Recently, many studies have been carried out on the microbial solubilization of phosphates as a substitute for chemical fertilizers. Indeed, most studies use agar plate screening as the initial strategy for selecting phosphate-solubilizing microorganisms based on the formation of a halo-zone around colonies. According to Nautiyal (1999), the criterion for the isolation of phosphate-solubilizing microorganisms based on the formation of a visible halo-zone on the Pikovskaya Agar medium is not a reliable technique because many isolates of microorganisms solubilize the phosphate (PSM) showing no clear area on agar plates, may be able to solubilize insoluble inorganic phosphates in a liquid medium. In addition, the studies of Rawat and Tewari (2011) and Promwee et al. (2014) reported that Trichoderma species showed good mycelial growth, but no formation of a halo-zone on the solid medium containing an insoluble inorganic phosphorus source. In contrast, the Zeroual et al. (2012) study has revealed that Aspergillus niger was able to form the halo-zone on the agar plate. 
Thus, the appearance of a clear zone on a solid medium should not be the only method to be tested for phosphate solubilization, additional tests should be undertaken simultaneously to evaluate the solubilization of phosphate in liquid medium. This may be because of the varying diffusion rates of different organic acids secreted by an organism (Johnston, 1952).

Quantitative estimation has shown that all the isolates used in this study have a capacity to solubilize phosphate in the liquid medium but at different concentrations during the 9 days. An increase in the concentration of soluble phosphorus in the culture filtrates was observed. This seems to correspond to phosphate sequestration by Trichoderma mycelium (Altomare et al., 1999; Nautiyal, 1999).

Kapri and Tewari (2010) suggested the disappearance of TCP after $96 \mathrm{~h}$ of incubation in some isolates of Trichoderma harzianum as demonstrated by a $100 \%$ solubilization percentage. This indicates the high potential of Trichoderma harzianum isolates for the solubilization of inorganic bound phosphate (TCP). In addition, in natural habitats, some phytopathogenic fungi such as Pythium and Rhizoctonia have been shown to be incapable of solubilizing phosphates and can be easily suppressed by the high competitive efficiency of T. harzianum by P absorption (Altomare et al., 1999). While other fungi, case of Aspergillus niger, have shown a high performance to solubilize different sources of phosphate (Zeroual et al., 2012). The solubilization of phosphates by Trichoderma species has been reported in several studies (Akintokun et al., 2007; Saravanakumar et al., 2013). Also, Silva et al. (2002), Alam et al. (2002), Soushie et al. (2007) worked on the study of fungal phosphate solubilization capacity in different solid and liquid culture media.

But the soluble phosphorus concentration in the broth began to decrease after the $12^{\text {th }}$ day of incubation. Kapri and Tewari (2010) who correlated the decrease of soluble phosphorus in culture broths with its sequestration in Trichoderma mycelium to be released in readily available form near the roots after mycelium lysis with age suggest the same results.

The addition of Trichoderma isolates to the MPB broth resulted in a lowering of the $\mathrm{pH}$ of the broths. Thus, Illmer and Schinner (1992) also reported that Penicillium and Pseudomonas have a tendency to decrease $\mathrm{pH}$ four days after culturing followed by a gradual increase during solubilization in liquid cultures. This appears to be consistent with phosphorus sequestration by Trichoderma mycelium (Altomare et al., 1999; Nautiyal, 1999). Kpomblekou and Tabatabai (1994) also show that microorganisms that tend to lower the $\mathrm{pH}$ of the medium during growth are effective solubilizers of phosphate. Similarly, the drop in $\mathrm{pH}$ in broth cultures has been reported in several studies that support lowering pH in this study (Vazquez et al., 2000; Alam et al., 2002; Rashid et al., 2004; Pradham and Sukla, 2005; Akintokun et al., 2007; Yadav et al., 2011; Saravanakumar et al., 2013; Promwee et al., 2014).

\section{Conclusion}

In addition to its ability in biological control against plant pathogens and the promotion of plant growth. Trichoderma spp. has also succeeded in showing its potential in the solubilization of phosphate rock. 
All Trichoderma isolates did not formed clear zone around the colonies during qualitative assessment and the most newly isolated fungi showed high solubilization percentages up to $95.39 \%$ in TR-TB 2000 isolate during quantitative estimation of phosphate solubilization.

There is a negative correlation between the $\mathrm{pH}$ level and the percentage of phosphate solubilization. The lowest $\mathrm{pH}$ values are found in Trichoderma isolates which gave the highest solubilization percentages.

Isolates with high performance in solubilizing rock phosphate showed higher fresh and dry mycelium weights.

\section{Acknowledgements}

"The Authors would like to acknowledge the support through the R and D Initiative - Appel à projets autour des phosphates APPHOS - sponsored by OCP (OCP Foundation, R and D OCP, Mohammed VI Polytechnic University, National Center of Scientific and technical Research CNRST, Ministry of Higher Education, Scientific Research and Professional Training of Morocco MESRSFC) under the project entitled *Sélection et utilisation des Trichoderma spp. pour l'amélioration de l'efficacité des phosphates et la lutte contre la pourriture racinaire du blé au Maroc * project ID *AGR-DOI-1/2017*

\section{Literature}

Achá, C. (2008): Aislamiento y multiplicación de cepas nativas de Trichoderma sp y su evaluación como biocontrolador de Fusarium sp y Rhizoctonia solani en plantas de tomate. Tesis de Licenciatura en Ingeniería Ambiental, pp. 1-94.

Afzal, A. and Asghari, B., (2008): Rhizobium and phosphate solubilizing bacteria improve the yield and phosphorus uptake in wheat (Triticum aestivum L.). Int. J. Agri. Biol., 10, 85-88.

Ahemad, M., Zaidi, A., Khan, M. S. and Oves, M. (2009): Biological importance of phosphorus and phosphate solubilizing microorganisms - an overview. In: M. S. Khan and A. Zaidi (eds): Phosphate Solubilizing Microbes for Crop Improvement. Nova, New York, pp. 1-4.

Akintokun, A. K., Akande, G. A., Akintokun, P. O., Popoola, T. O. S. and Babalola, A. O. (2007): Solubilization of insoluble phopshate by organic acid producing fungi isolated from Nigerian soil. International J. Soil Science 2, 301-307.

Alam, S., Khalil, S., Ayub, N. and Rashid, M. (2002): In vitro solubilization of inorganic phosphate by phosphate solubilizing microorganisms (PSM) from maize rhizosphere. International J. Agriculture and Biology 4, 454-458.

Altomare, C., Norvell, W. W., Bjorkman, T. and Harman G. E., (1999): Solubilization of phosphates and micronutrients by the plant-growth-promoting and biocontrol fungus Trichoderma harzianum Rifai 1295-22. Appl. and Environ. Microbiology 65, 2926-2933.

Balemi, T. and Negisho, K. (2012): Management of soil phosphorus and plant adaptation mechanisms to phosphorus stress for sustainable crop production: a review. J. Soil Sci. Plant Nutr., 12, 547-556.

Davet, P. (1979): Technique pour l'analyse des populations de Trichoderma et de Gliocladium virens dans le sol. Ann. Phytopathol. 11, 529-533.

Davet, P. (1996): Vie microbienne du sol et production végétale. Ed. INRA, Paris, 380 p.

De Santiago, A., García-López, A. M., Quintero, J. M., Avilés, M. and Delgado, A. (2013): Effect of Trichoderma asperellum strain T34 and glucose addition on iron nutrition in cucumber grown on calcareous soils. Soil Biol. Biochem. 57, 598-605.

De Trogoff, H. and Ricard, J. L. (1976): Biological control of Verticillium malthousei by Trichoderma viride spray on casing soil in commercial mushroom production [Fungal diseases, biological control]. Plant Dis. Rep. 60, 677-680. 
Dumitras, L. and Fratilescu-Sesan, T. (1980): Aspects of the antagonism of Trichoderma viride to Pythium debaryanum. Rev. Plant Pathol. 59, 1571.

Elad, Y., Chet, I. and Henis, Y. A. (1981): A selective medium for improving quantitative isolation of Trichoderma spp. from soil. Phytoparasitica 9, 59-67.

Fernández, L., Zalba, P., Gómez, M. and Sagardoy, M. (2007): Phosphate-solubilization activity of bacterial strains in soil and their effect on soybean growth under greenhouse conditions. Biol. Fertil. Soils 43, 805-809.

Fiske, C. H. and Subbarow, Y. (1925): The colorimetric determination of phosphorus. J. Biological Chemistry $66,375-400$.

Gindrat, D., van der Hoeven, E. and Moody, A. R. (1977): Control of Phomopsis sclerotioides with Gliocladium roseum or Trichoderma. Neth. J. PL. Path. 83, 9-438.

Gravel, V., Antoun, H. and Tweddell, R. J. (2007): Growth stimulation and fruit yield improvement of greenhouse tomato plants by inoculation with Pseudomonas putida or Trichoderma atroviride: Possible role of indole acetic acid (IAA). Soil Biol. Biochemistry 39, 1968-1977.

Hannan, N. R., Segeritz, C. P., Touboul, T. and Vallier, L. (2013): Production of hepatocyte-like cells from human pluripotent stem cells. Nat. Protoc. 8, 430-437.

Harman, G. E. (2000): Myths and dogmas of biocontrol: changes in perceptions derived from research on Trichoderma harzianum T-22. Plant Disease 84, 377-393.

Harman, G. E. (2006): Overview of mechanisms and uses of Trichoderma spp. Phytopathology 96, 190-194.

Harman, G. E., Howell, C. R., Viterbo, A., Chet, I. M. and Lorito, M. (2004): Trichoderma species opportunistic, avirulent plant symbionts. Nature Reviews Microbiology 2, 43-56.

Holford, I. C. R. (1997): Soil phosphorus: its measurement and its uptake by plants. Australian J. Soil Research 35, 227-239.

Illmer, P. and Schinner, F. (1992): Solubilization of hardly-soluble AlPO4 with P-solubilizing microorganisms. Soil Biol. and Biochem., 24, 389-395.

Johnston, H. W. (1952): The solubilization of phosphate: the action of various organic compounds on dicalcium and tri-calcium phosphate. New Zealand J. Sci. Technol. 33, 436-444.

Kapgate, C. A. and Rane, V. I. (2016): Antagonistic action of Trichoderma sp. on Colletorichum graminicola causing anthracnose on sugarcane in Gondia district (M.S.). Int. J. Pure App. Biosci. 4, 133-136.

Kapri, A. and Tewari, L. (2010): Phosphate solubilization potential and phosphatase activity of rhizospheric Trichoderma spp. Braz. J. Microbiol. 41, 787-795.

Kelley, W. D. (1976): Evaluation of Trichoderma harzianum impregnated clay granules as biocontrol for Phytophthora cinamomi causing damping-off of pine seedling. Phytopathology 66, 1023-1027.

Khan, M. S., Zaidi, A., Wani, P. A., Ahemad, M. and Oves, M. (2009): Functional diversity among plant growth-promoting rhizobacteria. In: M. S. Khan, A. Zaidi and J. Musarrat (eds): Microbial Strategies for Crop Improvement. Springer, Berlin, pp. 105-132.

Kpomblekou, A. K. and Tabatabai, M. A. (1994): Effect of organic acids on the release of phosphorus from phosphate rocks. Soil Sci. 158, 112-118.

Lang, S. F., Destain, J., Druart, P., Ongena, M. and Thonart, P. (2016): Les microorganismes dans le maintien de l'équilibre et la réhabilitation des écosystèmes de mangrove pollués par les hydrocarbures. Revue bibliographique. Int. J. Biol. Chem. Sci. 10, 2268-2284.

Machado, R. G., Sá, E. L. S., Damasceno, R. G., Hahn, L., Almeida, D., Moraes, T. and Camargo, F.A.O., Reartes D. S. (2011): Promotion of growth in plants Lotus corniculatus L. (birdsfoot trefoil) and Avena strigosa Schreb (black oat), by inoculation with rhizobia and Trichoderma harzianum. Sci. Nat. 33, 111126.

Nautiyal, C. S. (1999): An efficient microbiological growth medium for screening phosphate solubilizing microorganisms. FEMS Microbiol. 170, 265-270.

Oliveira, A. G., Chagas, Jr.A. F., Santos, G. R., Miller, L. O. and Chagas, L. F. B. (2012): Potential phosphate solubilization and AIA production of Trichoderma spp. Green J. Agroecol. Sust. Develop. 7, 149-155.

Peleg, Y., Addison, R., Aramaya, R. and Metzenberg, R. L. (1996): Translocation of Neurospora crassa transcription factor NUC-1 into the nucleus is induced by phosphate limitation. Fungal Genet. Biol. 20, $185-191$. 
Pikovskaya, R. I. (1948): Mobilization of phosphorus in soil connection with the vital activity of some microbial species. Microbiologiya 17, 362-370.

Pradham, N. and Sukla, L. B. (2005): Solubilization of inorganic phosphates by fungi isolated from agriculture soil. African J. Biotechnology 5, 850-854.

Promwee, A., Issarakraisila, M., Intana, W., Chamswarng, C. and Yenjit, P. (2014): Phosphate solubilization and growth promotion of pubber tree (Hevea brasiliensis Muell. Arg.) by Trichoderma strains. J. Agric. Sci. 6, 1916-9760.

Rashid, M., Khalil, S., Ayub, N., Alam, S. and Latif, F. (2004): Organic acids production and phosphate solubilization by phosphate solubilizing microorganisms (PSM) under in vitro conditions. Pakistan J. Biol. Sci. 7, 187-196.

Rawat, R. and Tewari, L. (2011): Effect of abiotic stress on phosphate solubilization by biocontrol fungus Trichoderma sp. Curr. Microbiol. 62, 1521-1526.

Rishbeth, J. (1979): Modern aspects of biological control of Fomes and Armillaria. Eur. J. For. Path. 9, 331-340.

Santos, H. A., Mello, S. C. M. and Peixoto, J. R. (2010): Association of isolates of Trichoderma spp. and indole-3-butyric acid (iba) in promoting root and growth of passion. Biosci. J. 26, 966-972 (in Portuguese).

Saravanakumar, K., Arasu, V. S. and Kathiresan, K. (2013): Effect of Trichoderma on soil phosphate solubilization and growth improvement of Avicennia marina. Aquatic Botany 104, 101-105.

Schachtman, D. P., Reid, R. J. and Ayling, S. M. (1998): Phosphate uptake by plants: from soil to cell. Plant Physiology 116, 447-453.

Shenoy, V. V. and Kalagudi, G. M. (2005): Enhancing plant phosphorus use efficiency for sustainable cropping. Biotechnol. Adv. 23, 501-513.

Silva Filho, G. N., Narloch, C. and Scharf, R. (2002): Solubilization of natural phosphates by microorganisms isolated from Pinus and Eucalyptus plantations in Santa Catarina. Brazil. Pesqui. Agropecu. Bras. 37, $847-854$.

Sobal, M., Martinez-carrera, D., Morales, P. and Roussos, S. (2007): Classical Characterization of mushroom genetic resources from temperates and tropical region of Mexico. Micol. Apl. Int. 19, 15-35.

Soushie, El., Azcon, R., Barea, J. M., Saggin, J. and Silva, E. M. R. (2007): Solubilização de fosfatos em meio sólido e líquido por bactérias e fungos do solo. Pesq. Agropec Bras. 40, 1149-1152.

Sujatha, E., Girisham, S. and Reddy, S. M. (2004): Phosphate solubilization by thermophilic microorganisms. Indian J. Microbiol., 44, 101-104.

Vazquez, P., Holguin, G., Puente, M. E., Lopez-Cortes, A. and Bashan, Y. (2000): Phosphate-solubilizing microorganisms associated with the rhizosphere of mangroves in a semiarid coastal lagoon. Biol. Fertil. Soils 30, 460-468.

Vinalea, F., Sivasithamparamb, K., Ghisalbertic, M. L., Marra, R., Woo, S. L and Lorito, M. (2008): Trichoderma-plant-pathogen interactions. Soil Biology and Biochemistry 40, 1-10.

Wang, X., Wang, Y., Tian, J., Lim, B. L., Yan, X. and Liao, H. (2009): Over expressing AtPAP15 enhances phosphorus efficiency in soybean. Plant Physiol. 151, 233-240.

Yadav, J., Verma, J. P. and Tiwari, K. N. (2011): Plant growth promoting activities of fungi and their effect on chickpea plant growth. Asian J. Biol. Sci. 4, 291-299.

Yedidia, I., Benhamou, N. and Chet, I. (1999): Induction of defence responses in cucumber plants (Cucumis sativus L.) by the biocontrol agent Trichoderma harzianum. Appl. and Environ. Microbiol., 65, 1061-1070.

Zeroual, Y., Chadghan, R., Hakam, A. and Kossir, A. (2012): Biosolubilization of mineral insoluble phosphates by immobilized fungi (Aspergillus niger) in fluidized bed bioreactor. J. Biotechnol. Biomaterial S6:004. doi:10.4172/2155-952X.S6-004. 
